\title{
PEMBUATAN POMPA SUMUR DALAM (DEEP WELL) UNTUK MENYEDIAKAN AIR BERSIH BAGI MASYARAKAT
}

\author{
Budi Utomo', Suri Mutia Siregar $^{2}$, Kasmir Tanjung ${ }^{3}$ \\ ${ }^{1}$ Fakultas Kehutanan, Universitas Sumatera Utara \\ ${ }^{2}$ Fakultas Psikologi, Universitas Sumatera Utara \\ ${ }^{3}$ Fakultas Teknik, Universitas Sumatera Utara \\ budiutomo@usu.ac.id, suri.mutia@usu.ac.id, kasmir@usu.ac.id
}

\begin{abstract}
Abstrak
Indonesia merupakan negara dengan sumber daya air yang melimpah. Hasil riset Pusat Penelitian dan Pengembangan Sumber Daya Air Kementrian Pekerjaan Umum tahun 2009 menunjukkan, Indonesia memiliki cadangan air yang cukup besar yaitu sebanyak $2.530 \mathrm{~km}^{3}$ atau peringkat kelima di dunia. Namun demikian, beberapa daerah di Indonesia masih memiliki masalah terhadap akses air bersih, salah satunya adalah Desa Pekan Sawah, Provinsi Sumatera Utara. Sebagian besar masyarakat di daerah tersebut belum memiliki fasilitas kamar mandi, serta masih memanfaatkan sungai sebagai sarana mandi - cuci - kakus (MCK). Tingkat kesejahteraan masyarakat yang masih berada pada tahapan prasejahtera, serta kondisi tanah yang mengandung batu menyulitkan masyarakat menggali sumur. Pengabdian ini bertujuan untuk menyediakan sarana air bersih bagi warga Desa Pekan Sawah dengan membuat pompa sumur dalam (deep well). Pompa sumur dalam adalah jenis pompa yang dapat digunakan untuk sumur yang sangat dalam, mulai dari $30 \mathrm{~m}$ hingga $\geq 100 \mathrm{~m}$. Penggunaan pompa sumur dalam dapat memberikan sumber air yang melimpah, serta bebas dari kontaminasi kotoran dan bahan kimia berbahaya. Tim Pengabdian telah berhasil membangun sumur sedalam $70 \mathrm{~m}$. Sumur dilengkapi dengan 2 mesin yang dapat memenuhi menara air berkapasitas $2000 \mathrm{~L}$ dalam waktu 30 menit. Saat ini, sumur tersebut telah memasok kebutuhan air untuk 50 rumah tangga.
\end{abstract}

Kata Kunci : air bersih, pompa sumur dalam, desa pekan sawah

\section{PENDAHULUAN}

Air dan sanitasi layak adalah kebutuhan dasar manusia. Keberadaan air harus dilestarikan agar tetap dapat dimanfaatkan dengan baik oleh manusia maupun makhluk hidup lainnya (Zarkasih, Rohmat, dan Nur, 2018). Salah satu poin dalam tujuan pembangunan berkelanjutan (sustainable development / SDGs) pada sektor lingkungan hidup adalah memastikan masyarakat mencapai akses universal air bersih dan sanitasi. Kementrian PPN / Bappenas menyebutkan bahwa pada tahun 2004, Bank Dunia mencatatkan 780 juta orang di dunia tidak memiliki akses air bersih dan lebih dari 2 miliar penduduk bumi tidak memiliki akses terhadap sanitasi. Akibatnya, ribuan nyawa melayang setiap hari dan kerugian materi mencapai 7 persen dari PDB dunia Kementrian Perencanaan Pembangunan Nasional (nd).

Alihar (2018) menyebutkan air merupakan salah satu komponen lingkungan hidup yang sangat dibutuhkan untuk pertumbuhan dan perkembangan manusia. Air bersih dibutuhkan manusia untuk mengisi cairan tubuh serta menunjang beberapa kegiatan kehidupan lainnya seperti memasak, mandi, dan sebagainya. Kualitas air yang buruk dapat menyebabkan beberapa penyakit, seperti diare, kolera, disentri, tifus, cacingan, penyakit kulit, hingga keracunan (Direktorat Promosi Kesehatan

$$
\text { Teknologi Tepat Guna }
$$


dan Pemberdayaan Masyarakat Kementrian Kesehatan, 2020).

Indonesia merupakan negara tropis yang memiliki cadangan air yang berlimpah. Hasil riset Pusat Penelitian dan Pengembangan Sumber Daya Air Kementrian Umum tahun 2009 menunjukkan, Indonesia memiliki sediaan air sebanyak $2.530 \mathrm{~km}^{3}$ atau peringkat kelima di dunia. Namun demikian, pada kenyataannya, belum semua rakyat Indonesia memiliki akses yang mudah terhadap air bersih.

Pertumbuhan jumlah penduduk yang tinggi di Indonesia menyebabkan tidak semua komponen masyarakat dapat menikmati air bersih. Susana (2003) menyebutkan bahwa sumber air bersih yang dibutuhkan untuk bahan baku air bersih yang bebas dari pencemaran semakin sulit untuk diperoleh, karena air banyak tersedot oleh kegiatan industri yang memerlukan sejumlah air dalam menunjang produksinya. Selain itu, masyarakat yang berasal dari kalangan bawah (miskin) dan tidak terdidik juga mengalami kesulitan untuk mendapatkan akses air bersih. Beberapa golongan masyarakat masih memanfaatkan air sungai untuk kebutuhan minum rumah tangganya, padahal berdasarkan laporan oleh Direktorat Jenderal Pengendalian Pencemaran dan Kerusakan Lingkungan Kementrian Lingkungan Hidup dan Kehutanan (KLHK) di tahun 2015 menerangkan bahwa hampir 68 persen mutu air sungai di 33 provinsi di Indonesia dalam status tercemar berat (Kementrian Lingkungan Hidup dan Kehutanan Republik Indonesia, 2017).

Pencemaran air di wilayah perkotaan dan pedesaan Indonesia masih menjadi masalah serius. Bank Dunia (2013) mencatatkan bahwa Indonesia mengalami dampak ekonomi yang signifikan akibat buruknya sanitasi di Indonesia. Sebuah studi yang dilakukan oleh Water and Sanitation (WSP) memperkirakan bahwa Indonesia kehilangan Rp. 56 triliun (USD 6,3 milyar) pada tahun 2007 akibat buruknya kondisi sanitasi dan kebersihan, atau setara dengan sekitar 2,3 persen dari GDPnya. Hastuti dan Nuraeni (2017) menyebutkan, salah satu penyebab terjadinya pencemaran air berkaitan dengan kurangnya akses ketersediaan infrastruktur air bersih dan sanitasi. Purwanto (2020) menyebutkan bahwa hingga tahun 2018, akses air minum layak di Indonesia masih mencapai $87,75 \%$ dari total populasi, dan yang menikmati akses perpipaan baru sekitar 20,14\%.

Desa Pekan Sawah merupakan salah satu Desa di Indonesia yang terletak di Kecamatan Sei Bingei, Kabupaten Langkat, Provinsi Sumatera Utara. Desa ini berjarak $75 \mathrm{~km}$ dari Ibu Kota Sumatera Utara, yaitu Kota Medan, dan 30 km dari Kota Binjai. Desa ini dapat dicapai menggunakan kenderaan bermotor dalam kurun waktu 1 jam melalui jalan aspal dari Kota Binjai. Secara geografis, Desa ini terletak pada daratan yang relatif datar, serta dilewati oleh aliran Sungai Bingei yang berasal dari Taman Nasional Gunung Leuser.

Sejumlah masyarakat yang tinggal di Desa Pekan Sawah belum mencapai kondisi sejahtera secara ekonomi. Pemerintah Kabupaten Langkat (2016) menyebutkan bahwa jumlah penduduk miskin di Kabupaten Langkat pada tahun 2013 adalah sebanyak 104.310 jiwa atau $10.44 \%$ dari total penduduk. Aminah (2018) menyebutkan bahwa berdasarkan basic data terpadu (BDT) program bantuan sosial untuk tahun 2017, jumlah warga miskin di Kabupaten Langkat diperkirakan lebih kurang mencapai $40 \%$ dari total penduduk. Data miskin tersebut diperoleh karena penghasilan sebagian masyarakat berada di bawah rata-rata penghasilan nasional.

Rendahnya penghasilan masyarakat di Desa Pekan Sawah menyebabkan sejumlah rumah belum memiliki sanitasi dan akses air bersih yang memadai. Beberapa warga, khususnya yang bertempat tinggal di Dusun 7 Desa Pekan Sawah belum memiliki kamar mandi di rumah dan memanfaatkan air Sungai Bingei untuk beragam keperluan rumah tangga seperti memasak, mencuci, mandi, buang air, dan sebagainya. Sungai bingei merupakan sungai yang memiliki panjang $67 \mathrm{~km}$, lebar $30 \mathrm{~m}$, dan luas potensi sempadan sebesar 3,35 $\mathrm{km}^{2}$ (Pemerintah Kabupaten Langkat, 2016). Sungai Bingei merupakan salah satu sungai yang memiliki debit air yang besar, sehingga pemerintah membangun bendungan (DAM) Namu Sira-Sira untuk memasok air bagi areal persawahan masyarakat yang ada di sekitar sungai.

Perilaku masyarakat dalam memanfaatkan sungat sebagai tempat mandi, cuci, dan kakus (MCK) merupakan fenomena yang patut dicermati. Penggunaan sungai sebagai sarana MCK dapat menimbulkan persoalan tersendiri, terutama

$$
\text { Teknologi Tepat Guna }
$$

174 
berkaitan dengan kebersihan dan kesehatan lingkungan. Puspitasari (2007) menyebutkan bahwa pencemaran terhadap sumber daya air dapat mengganggu lingkungan abiotik, biotik, dan lingkungan sosial. Ada banyak organisme, biota hewan, dan tumbuhan yang menjadi rusak atau mati karena pencemaran. Warga yang mendiami daerah di sekitar bibir sungai juga akan rentan terkena penyakit akibat adanya zat-zat yang merugikan tubuh, yang ditemukan dalam sungai atau sumber air yang telah tercemar. Turunnya kualitas kesehatan lingkungan akan berdampak pada 4 hal, yaitu : (1) terjadinya disparitas status kesehatan; (2) mewabahnya penyakit seperti diare dan penyakit kulit; (3) terbentuknya perilaku masyarakat yang kurang mendukung pola hidup bersih dan sehat; dan (4) rendahnya kualitas kesehatan penduduk miskin dan terbatasnya tenaga kesehatan yang distribusinya juga tidak merata.

Jika dilihat dari aspek hukum, penggunaan sungai sebagai sarana MCK di Indonesia juga tidak diperbolehkan karena dapat merusak kualitas lingkungan hidup. Peraturan Pemerintah Nomor 35 Tahun 1991 tentang sungai pasal $27 \mathrm{Bab}$ XII menyebutkan bahwa masyarakat dilarang membuang benda-benda / bahan-bahan padat dan/atau cair ataupun yang berupa limbah ke dalam maupun di sekitar sungai yang diperkirakan atau patut diduga akan menimbulkan pencemaran atau menurunkan kualitas air, sehingga membahayakan dan/atau merugikan penggunaan air yang lain dan lingkungan (Presiden Republik Indonesia, 1991). Ancaman pidana bagi pelaku pelanggaran adalah hukuman penjara selama-lamanya 2 (dua) tahun dan atau denda setinggi-tingginya Rp. 5.000.000; (lima juta rupiah) (Presiden Republik Indonesia, 1974).

Akses terhadap air bersih juga merupakan salah satu sarana untuk menciptakan perilaku hidup bersih dan sehat (PHBS). Kementrian Kesehatan Republik Indonesia pada tahun 2013 (dalam Kospa dan Rahmadi, 2019) mengemukakan bahwa PHBS di lingkungan keluarga memiliki beberapa indikator, diantaranya adalah (1) menggunakan air bersih dan sehat karena berbagai penyakit dan resiko kesehatan ditularkan melalui media air, seperti bakteri, virus, dan bahan-bahan kimia berbahaya. Oleh karena itu, menggunakan air yang bersih dan sehat menjadi komponen yang sangat dipertimbangkan; (2) mencuci tangan menggunakan sebelum makan, setelah dari toilet, atau sehabis bekerja dapat mencegah terjadinya infeksi bakteri dan virus; dan (3) menggunakan jamban sehat untuk mencegah terjadinya kontaminasi silang hasil ekskreta manusia ke sumber air dan makanan dalam keluarga.

Perilaku sejumlah masyarakat Desa Pekan Sawah yang masih memanfaatkan sungai sebagai sarana MCK juga disebabkan oleh kesulitan masyarakat untuk membangun sarana air bersih. Tingginya kandungan batuan pada areal tanah di Desa Pekan Sawah, khususnya di Dusun 7 menyebabkan penduduk kesulitan untuk menggali sumur di wilayah tersebut. Hampir seluruh rumah di kawasan Dusun 7 belum memiliki kamar mandi dan kakus di rumah, sehingga masyarakat melakukan perilaku buang air di sungai atau di sembarang tempat.

Berdasarkan uraian permasalahan di atas, Tim Pengabdian Desa Binaan USU bermaksud untuk membantu masyarakat Desa Pekan Sawah dalam membangun sarana air bersih. Tim Pengabdian berencana untuk membuat pompa sumur dalam (deep well). Pompa sumur dalam (deep well) adalah jenis pompa yang dapat digunakan untuk sumur yang sangat dalam, mulai dari $30 \mathrm{~m}$ hingga $\geq 100 \mathrm{~m}$. Penggunaan pompa sumur dalam dapat memberikan sumber air yang melimpah, minim masalah teknis, serta bebas dari kontaminasi kotoran dan bahan kimia berbahaya. Selain pompa sumur dalam, Tim juga akan menyediakan menara air untuk menampung persediaan air. Melalui aplikasi ilmu pengetahuan dan teknologi ini, Tim Pengabdian yakin akan mampu memperbaiki permasalahan yang tengah dihadapi oleh masyarakat dusun 7 Desa Pekan Sawah

\section{METODE}

Tim Pengabdian Universitas Sumatera Utara melakukan beberapa langkah dalam melaksanakan pengabdian di Desa Pekan Sawah, yakni :

1. Menyelenggarakan diskusi antara Tim Pengabdian dengan Kepala Desa Pekan Sawah, Aparat Desa, dan Perwakilan Masyarakat Desa Pekan Sawah;

2. Menyelenggarakan diskusi bersama seluruh anggota Tim Pengabdian mengenai solusi dari permasalahan masyarakat di Desa Pekan Sawah;

Teknologi Tepat Guna 175 
3. Melakukan analisis pasar berkaitan dengan ketersediaan bahan baku pembentuk produk yang akan dirancang untuk mengatasi permasalahan masyarakat Desa Pekan Sawah;

4. Melaksanakan analisis kemampuan bengkel / workshop di Fakultas Teknik USU dalam hal perancangan produk;

5. Melakukan perancangan produk untuk menyelesaikan permasalahan masyarakat Desa Pekan Sawah;

6. Melaksanakan instalasi peralatan produk di Desa Pekan Sawah; dan

7. Menyebarluaskan informasi mengenai pemeliharaan dan pemanfaatan produk untuk keberlangsungan program kepada masyarakat Desa Pekan Sawah.

\section{HASIL DAN PEMBAHASAN}

\section{Diskusi Permasalahan yang dihadapi oleh Mitra}

Pelaksanaan diskusi antara Tim Pengabdian

Desa Binaan USU dengan Kepala Desa Pekan Sawah, Aparat Desa, dan beberapa perwakilan Masyarakat Desa telah berlangsung di Kantor Kepala Desa Pekan Sawah. Berdasarkan hasil diskusi, ditemukan bahwa hampir seluruh rumah di Dusun 7 Desa Pekan Sawah belum memiliki kamar mandi dan kakus di rumah, sehingga masih memanfaatkan air Sungai Bingei untuk keperluan MCK. Rendahnya kesejahteraan masyarakat dan kondisi tanah yang mengandung bebatuan juga mengakibatkan masyarakat belum mampu untuk membangun sumur di Dusun 7 Desa Pekan Sawah. Selain itu, masyarakat juga mengeluhkan kondisi air dari sumur yang ada di Dusun 7 kotor dan berbau karat.

\section{Analisis Metode Penyelesaian Masalah}

Pelaksanaan diskusi mengenai metode penyelesaian masalah masyarakat Desa Pekan Sawah. Berdasarkan hasil diskusi, Tim Pengabdian Desa Binaan memutuskan untuk membangun pompa sumur dalam sebagai salah solusi untuk menyediakan sarana air bersih di Desa Pekan Sawah.

\section{Analisis Ketersediaan Bahan Baku Pembentuk Produk}

Pelaksanaan analisis pasar berkaitan dengan ketersediaan bahan baku pembentuk pompa sumur dalam seperti pipa tanah tekanan, pompa submersible, menara air, iron tower, mesin las, baut, mur, listrik, meteran listrik, pemutus arus saat terjadi short sircuit, dan sebagainya. Analisis pasar dilakukan di sejumlah toko material dan Fakultas Teknik USU. Berdasarkan hasil analisis, Tim Pengabdian Desa Binaan dapat memastikan bahwa seluruh bahan baku tersedia di pasar dan mudah untuk diperoleh.

\section{Analisis Kemampuan Bengkel / Workshop untuk Membuat Pompa Sumur Dalam}

Pelaksanaan analisis kemampuan bengkel / workshop dilakukan untuk mendata kemampuan bengkel / workshop Fakultas Teknik USU untuk membuat bagian-bagian dari sumur dalam. Berdasarkan hasil analisis, ditemukan bahwa beberapa bagian dari proses pembuatan pompa sumur dalam dapat dikerjakan di laboratorium Fakultas Teknik USU, dan beberapa bagian sisanya akan dikerjakan langsung di lokasi instalasi pompa sumur dalam.

\section{Perancangan Produk untuk Menyelesaikan Permasalahan Masyarakat Desa Pekan Sawah}

Pelaksanaan perancangan pompa sumur dalam untuk menyelesaikan permasalahan masyarakat Desa Pekan Sawah adalah dengan menghasilkan sebuah gambar/ilustrasi produk dan pembuatan bagian-bagian dari produk di bengkel/workshop. Berikut ini merupakan ilustrasi dari mesin pompa sumur dalam dan menara air yang akan digunakan untuk menyelesaikan permasalahan masyarakat di Desa Pekan Sawah.

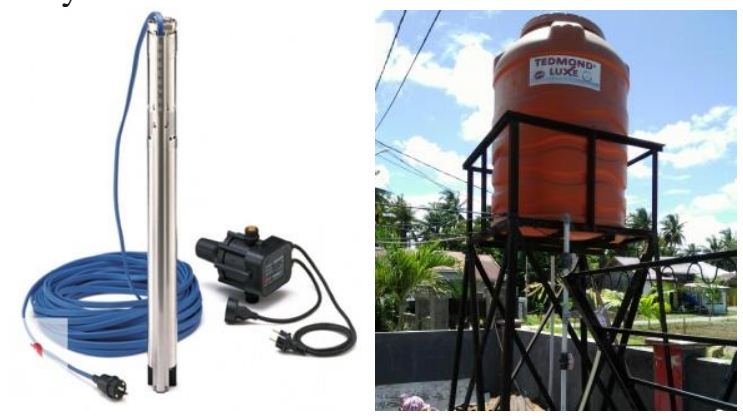

Gambar 1. ( Ilustrasi submersible pump dan water tank yang direncanakan akan digunakan) 


\section{Instalasi Peralatan Produk di Desa Pekan} Sawah

Pelaksanaan instalasi pompa sumur dalam di Desa Pekan Sawah dimulai di lokasi yang ditunjuk oleh Kepala Desa Pekan Sawah. Tim Pengabdian Desa Binaan menggali sumur sedalam $70 \mathrm{~m}$, memasang iron tower, dan melengkapi sumur dengan menara air berkapasitas $2000 \mathrm{~L}$.

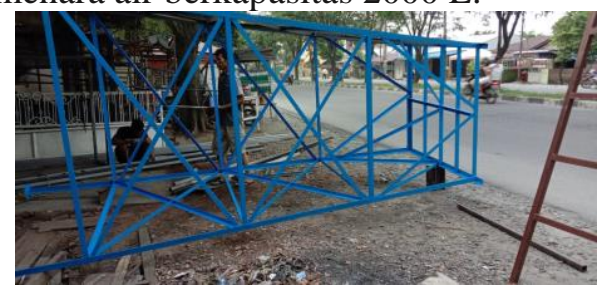

Gambar 2. (Proses instalasi pompa sumur dalam di Desa Pekan Sawah)

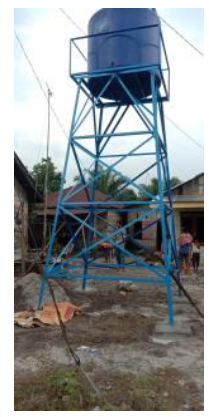

Gambar 3. (Pompa sumur dalam di Desa Pekan

\section{Sawah sebelum Uji Coba)}

Setelah proses instalasi selesai, Tim Pengabdian Desa Binaan melakukan uji coba sumur dalam. Berdasarkan hasil uji coba, air yang dikeluarkan tampak jernih, tidak berbau, dan tidak berwarna. Namun, debit air yang dihasilkan termasuk lemah sehingga membutuhkan waktu yang cukup lama untuk memenuhi menara air.

Lambatnya proses pengisian menara air membuat Tim Pengabdian untuk melakukan perbaikan terhadap sumur. Setelah melewati serangkaian diskusi, Tim akhirnya memutuskan untuk menambah mesin dan membangun bak penampungan sementara di bagian bawah sumur.

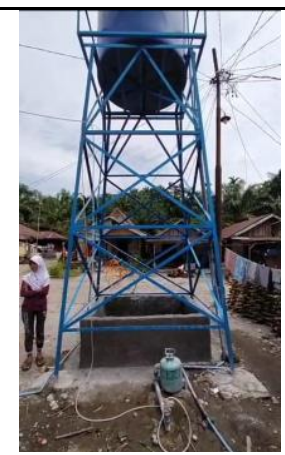

Gambar 4. (Sumur dalam di Desa Pekan Sawah setelah penambahan mesin dan bak penampungan air)

Setelah proses perbaikan sumur selesai, Tim Pengabdian Desa Binaan kemudian melakukan uji coba kembali, dan hasilnya menara air yang berkapasitas $2000 \mathrm{~L}$ dapat penuh hanya dalam waktu 30 menit. Pompa sumur dalam juga bekerja secara otomatis, sehingga ketika terjadi kekurangan air pada menara, pompa akan langsung memenuhinya kembali. Setelah pelaksanaan instalasi sumur selesai dilakukan, Tim Pengabdian bersama perangkat Desa Pekan Sawah melakukan instalasi pipa air ke 50 rumah di Desa Pekan Sawah untuk menyalurkan air.

\section{Penyebarluasan Informasi mengenai}

Pemeliharaan dan Pemanfaatan Produk untuk Keberlangsungan Program kepada Masyarakat Desa Pekan Sawah

Pelaksanaan penyebarluasan informasi mengenai pemeliharaan dan pemanfaatan pompa sumur dalam untuk keberlangsungan program kepada Masyarakat Desa Pekan Sawah dilakukan di lokasi instalasi pompa sumur dalam. Kondisi pandemi Covid-19, menjadikan Tim Pengabdian dan Kepala Desa memutuskan agar kegiatan penyebarluasan informasi hanya dihadiri oleh 5 orang perwakilan masyarakat

\section{KESIMPULAN}

Pembuatan pompa sumur dalam di Desa Pekan Sawah telah berhasil dilaksanakan. Pompa yang dirancang mampu memenuhi menara air berkapasitas $2000 \mathrm{~L}$ dalam waktu 30 menit secara otomatis.

Perancangan pompa sumur dalam ini telah membantu masyarakat Desa Pekan Sawah untuk

$$
\text { Teknologi Tepat Guna }
$$


mengakses air bersih. Sebelum pengabdian dilakukan, hampir seluruh rumah di Desa Pekan Sawah tidak memiliki akses terhadap air bersih, dan masih menggunakan air sungai sebagai sarana MCK. Setelah pengabdian, 50 rumah di Desa Pekan Sawah telah dapat menikmati air bersih yang disalurkan melalui pipa.

Sebagai upaya keberlanjutan program, Tim Pengabdian menyarankan kepada masyarakat untuk melakukan urunan, guna menyediakan biaya pemeliharaan maupun perbaikan pompa sumur dalam. Tim juga berharap agar pembangunan pompa sumur dalam dapat diselenggarakan di daerah-daerah lainnya yang belum memiliki sarana air bersih untuk mengurangi pencemaran air sungai.

\section{UCAPAN TERIMAKASIH}

Tim Pengabdian Desa Pekan Sawah mengucapkan terimakasih kepada Lembaga Pengabdian/Pelayanan Kepada Masyarakat Universitas Sumatera Utara (LPPM-USU) yang telah memberikan kesempatan berupa hibah dana untuk melaksanakan seluruh rangkaian pengabdian. Selain itu, Tim juga memberikan penghargaan kepada seluruh perangkat Desa Pekan Sawah yang telah memberikan dukungan selama kegiatan pengabdian berlangsung.

\section{REFERENSI}

Alihar, Fadjri. (2018). Penduduk dan Akses Air Bersih di Kota Semarang. Jurnal Kependudukan Indonesia, 13(67-76) : 2502-8537

Aminah, A.N. (2018). Warga Miskin Langkat Capai 40 Persen. Republika.co.id. 3 Maret 2018. Diakses dari : https://nasional.republika.co.id/berita/nasional/daera h/18/03/03/p50i3b384-warga-miskin-langkat-capai40-persen

Bank Dunia. (2013) . Kajian Sanitasi Perkotaan di Asia Timur dan Pasifik : Indonesia Ringkasan Eksekutif. Diakses dari : worldbank.org

Direktorat Promosi Kesehatan dan Pemberdayaan Masyarakat Kementrian Kesehatan. (2020). Manfaat Air Bersih dan Menjaga Kualitasnya. Diakses dari : promkes.kemkes.go.id
Kementrian Lingkungan Hidup dan Kehutanan Republik Indonesia. (2017). Petunjuk Teknis Restorasi Kualitas Air Sungai. Diakses dari : ppkl.menlhk.go.id

Kementrian Perencanaan Pembangunan Nasional. (nd). Sustainable Development Goals. Diakses dari : sdgs.bappenas.go.id

Hastuti dan Nuraeni. (2017). Pendekatan Sanitasi untuk Pemulihan Kondisi Air Tanah di Perkotaan : Studi Kasus Kota Cimahi, Jawa Barat. Jurnal Teknologi Lingkungan, 18 (70-79)

Kospa, H.S.D. dan Rahmadi. (2019). Pengaruh Perilaku Masyarakat terhadap Kualitas Air di Sungai Sekanak Kota Palembang. Jurnal Ilmu Lingkungan Volume 17 Issue 2 (2019) : 212 - 221, ISSN : 1829-8907

Pemerintah Kabupaten Langkat. (2016). Peraturan Daerah Kabupaten Langkat Nomor : 1 Tahun 2016 tentang Rencana Pembangunan Jangka Menengah Daerah Kabupaten Langkat Tahun 2014 2016. Diakses dari : https://jdihn.go.id/files/603/2019-1212_1576123181_PERDA-No-1---2016-(RPJMD2014---2019).pdf

Purwanto, E.W. (2020). Pembangunan Akses Air Bersih Pasca Krisis Covid-19. The Indonesian Journal of Development Planning, 4 (207 -214)

Puspitasari, D.E. (2007). Dampak Pencemaran Air terhadap Kesehatan Lingkungan dalam Perspektif Hukum Lingkungan (Studi Kasus Sungai Code di Kelurahan Wirogunan Kecamatan Mergangsan dan Keluragan Prawirodirjan Kecamatan Gondomanan Yogyakarta). Mimbar Hukum Volume 21, Nomor 1, Februari 2009, Hal. 23-34

Presiden Republik Indonesia. (1991). Peraturan Pemerintah No. 35 Tahun 1991 Tentang : Sungai. 14 Juni 1991. Diakses dari : sda.pu.go.id

Presiden Republik Indonesia. 1974. Undang - Undang Republik Indonesia Nomor 11 Tahun 1974 Tentang Pengairan. Diakses dari : sda.pu.go.id

Susana, Tutju. (2003). Air Sebagai Sumber Kehidupan. Oseana 3 (17-25) : 0216-1877

Zarkasih, Rohmat, Nur. (2018). Evaluasi Ketersediaan Air dan Tingkat Pemenuhan Kebutuhan Air di Sub DAS Cikeruh. Jurnal Pendidikan Geografi, 18 ( 72 - 80).

$$
\text { Teknologi Tepat Guna }
$$


Prosiding PKM-CSR, Vol. 3 (2020)

e-ISSN: 2655-3570 